\title{
Penanganan Tindak Pidana Kejahatan Premanisme di Wilayah Hukum Indragiri Hilir
}

\author{
Ali Azhar', Maryanto', Vivi Arfiani Siregar ${ }^{1}$ \\ ${ }^{1}$ Fakultas Hukum Universitas Islam Indragiri. \\ ${ }^{2}$ Anggota Advokat Indragiri Hilir \\ Email : sahabat.aliazhar@gmail.com.
}

\begin{abstract}
The phenomenon of street crime in Indragiri Hilir began to develop and is undeniable, this phenomenon gave birth to a group of criminals who commit violence. Prema violence in maintaining its existence, both in the social and economic fields. Because the economy is increasingly difficult and the higher the level of poverty. Thugs in the jurisdiction of the Indragiri Hilir Police Station began to increase in the area of community life. The purpose of this study is to determine the constraints and implementation of Law Enforcement on Thuggish Actions. This research method uses an empirical juridical approach, which means reviewing the state of the problem in the field is associated with applicable legal aspects and regulating the problem. The results of thugs in the jurisdiction of the Indragiri Hilir Police Station began to increase in the area of community life. Thugs do extortion (voluntary) with extortion on a voluntary or voluntary basis from the merchant community, the private community, especially in Tembilahan City. The number of cases of gangsterism in 2014 there were 27 cases of violent crime. the investigation process contained 21 cases, 21 cases were submitted to the prosecutor's office

Keywords: Criminal Thugs; Law enforcement; Public order
\end{abstract}

\begin{abstract}
Abstrak
Fenomena kejahatan jalanan di Indragiri Hilir mulai berkembang dan tidak dapat disangkal, fenomena ini melahirkan sekelompok penjahat yang melakukan kekerasan. Kekerasan prema dalam mempertahankan eksistensinya, baik di bidang sosial maupun ekonomi. Karena ekonomi semakin sulit dan semakin tinggi tingkat kemiskinan. Preman di wilayah hukum Kantor Polisi Indragiri Hilir mulai meningkat di bidang kehidupan masyarakat. Tujuan dari penelitian ini adalah untuk mengetahui kendala dan implementasi Penegakan Hukum atas Tindakan Premanisme. Metode penelitian ini menggunakan metode pendekatan yuridis empiris, yang berarti meninjau keadaan masalah di lapangan dikaitkan dengan aspek-aspek hukum yang berlaku dan mengatur masalah. Hasil penelitian Preman di wilayah hukum Kantor Polisi Indragiri Hilir mulai meningkat di bidang kehidupan masyarakat. Preman melakukan pemerasan (sukarela) dengan pemerasan atas dasar sukarela atau sukarela dari komunitas pedagang, komunitas swasta, khususnya di Kota Tembilahan. Jumlah kasus premanisme pada 2014 ada 27 kasus kejahatan dengan kekerasan. proses penyelidikan berisi 21 kasus, 21 kasus telah diserahkan ke kantor kejaksaan

Kata Kunci: Tindak Pidana Premanisme; Penegakan Hukum; Ketertiban Umum.
\end{abstract}

\section{PENDAHULUAN}

Menurut Dial et al. (2006) Negara hukum adalah negara yang komposisinya diatur oleh hukum sehingga semua kekuasaan pemerintah didasarkan pada hukum, rakyat tidak boleh bertindak sewenang-wenang sesuai dengan kehendak mereka sendiri, yang bertentangan dengan hukum. Saat ini tingkat kejahatan di Indonesia sangat tinggi dan jenis kejahatan berkembang dengan istilah kejahatan luar biasa (Fikri dan Azhar 2020). Peran dan fungsi Polisi Nasional sebagai aparatur negara yang menyediakan jasa keamanan dengan tujuan melindungi martabat dan martabat manusia sehingga masyarakat dapat melaksanakan produktivitasnya dengan aman, yang merupakan hak semua warga negara. Salah satu hal yang mengganggu situasi ideal ini adalah kejahatan, dan kejahatan premanisme adalah jenis kejahatan yang secara langsung menyentuh masyarakat (Azhar dan Fikri, 2020). Pelaksanaan mewujudkan rasa aman terhadap tindak pidana yang dilakukan oleh pelaku kejahatan premanisme mengharuskan Polisi sebagai petugas penegak hukum, 
Logika : Journal of Multidisciplinary Studies, p-ISSN 2085-997X. e-ISSN 2715-4505.

Vol. 11 Nomor 02 Desember 2020. 79-86.

pelindung dan penjaga masyarakat untuk melaksanakan tugasnya dengan serius berdasarkan profesionalisme menuju Kepolisian Nasional yang independen dan tepercaya harus mengambil langkah strategis untuk mengatasi kejahatan preman (Muharlisiani dkk. 2019).

Premanisme adalah tindak pidana kekerasan dan juga diatur dengan sangat jelas dalam KUHP yang diatur dalam Pasal 89 KUHP, (Pasal 365 KUHP), Pemerasan (Pasal 368 KUHP), pemerkosaan atau pemerkosaan (Pasal 285 KUHP), penganinyaan (Pasal 351 KUHP), kerusakan barang (Pasal 46o KUHP), yang tentu saja dapat mengganggu ketertiban umum dan menimbulkan keresahan di masyarakat.endahuluan meliputi latar belakang masalah, rumusan masalah (kalimat tanya berbentuk narasi) serta tujuan dan manfaat penelitian, rangkuman kajian teoritik yang berkaitan dengan masalah yang diteliti. Dilihat dari perkembangan kekerasan premanisme yang semakin tinggi di Indonesia, menurut analisis penulis sangat bertentangan dengan keberadaan Hukum Pidana yang berlaku di Indonesia. Bahwa Hukum Pidana adalah sejumlah peraturan hukum yang memuat larangan atau keharusan untuk pelanggaran yang diancam dengan sanksi pidana (sanksi hukum) bagi mereka yang membuatnya. Pemerintah Orde Baru mengeluarkan kebijakan membersihkan preman yang dikenal sebagai Petrus atau penembakan misterius. Lusinan dan bahkan ratusan preman ditembak mati secara misterius, kemudian tubuh mereka sengaja ditinggalkan dan tidak diurus di jalan raya untuk dilihat oleh penduduk (Asshiddiqie 1995), kebijakan penembak misterius membuat terapi kejut dan pengobatan kejut sehingga penjahat tidak berani bereaksi lagi.

Preman dalam melakukan tindak pidana yang melanggar Hukum Pidana, preman tidak diadili oleh pihak berwenang, hanya preman yang diberikan arahan dan petunjuk. Penulis mengambil daerah Kabupaten Indragiri Hilir sebagai salah satu daerah yang memiliki tingkat kejahatan premanisme yang cukup tinggi. Kabupaten Indragiri Hilir yang populasinya didominasi oleh para pendatang ini, sehingga kondisi ini berpengaruh pada karakter warganya yang cenderung keras dan berani. Tidak dapat dipungkiri bahwa fenomena ini melahirkan sekelompok orang, dalam hal ini preman yang melakukan kekerasan dalam mempertahankan eksistensinya, baik di bidang sosial maupun ekonomi. Sehingga ada pendapat bahwa Kabupaten Indragiri Hilir adalah kabupaten yang masih banyak preman (Syari dan Email 2016). Preman di wilayah hukum Polres Indragiri Hilir sebenarnya telah terjadi di banyak bidang kehidupan masyarakat. Sebagai pungutan liar (sukarela) baik sukarela maupun paksaan yang mengganggu komunitas pedagang pada umumnya, masyarakat swasta khususnya di Kota Tembilahan .

\section{METODE PENELITIAN}

Penelitian ini menggunakan metode pendekatan yuridis empiris, yang berarti meninjau keadaan masalah di lapangan dikaitkan dengan aspek-aspek hukum yang berlaku dan mengatur masalah (Nugroho dkk, 2017). Jika dilihat dari sifatnya, penelitian ini diklasifikasikan sebagai deskriptif, artinya penelitian ini menjelaskan bagaimana penegakan hukum pidana dilakukan oleh preman di Kabupaten Indragiri Hilir, Indragiri Hilir. 
Logika : Journal of Multidisciplinary Studies, p-ISSN 2085-997X. e-ISSN 2715-4505.

Vol. 11 Nomor 02 Desember 2020. 79-86.

\section{HASIL DAN PEMBAHASAN}

\section{Implementasi Penegakan Hukum atas Tindakan Premanisme oleh Polisi Kabupaten Indragiri Hilir}

Substansi hukum, undang-undang tersebut dibuat oleh lembaga yang berwenang, misalnya UU dibuat oleh Dewan Perwakilan Rakyat (DPR), dalam menciptakan substansi atau isi UU DPR sebagai lembaga yang berwenang harus memperhatikan apakah isi UU tersebut hukum benar-benar akan memberikan keadilan, kepastian hukum dan bermanfaat bagi masyarakat atau bahkan pembuatan hukum akan semakin menciptakan ketidakadilan dan ketidakpastian dan bahkan merugikan masyarakat (Wandi 2020). Penegakan hukum terhadap premanisme oleh Polres Indragiri Hilir saat ini tidak dilaksanakan secara optimal. Disebabkan oleh banyak aksi kekerasan, baik yang dilakukan oleh anak-anak, remaja maupun orang dewasa. Substansi hukum premanisme oleh Polisi Resor Inragiri Hilir pada tahun 2018 disajikan pada tabel 1 :

TabelL 1. Substansi Hukum terhadap Premanisme pada tahun 2018

\begin{tabular}{llll}
\hline No & Jawaban Responden & Jumlah Responden & Persen \\
\hline 1 & ditegakkan & 15 & 30 \\
2 & Kurang ditegakkan & 15 & 30 \\
3 & Tidak ditegakkan & 20 & 40 \\
\hline Total & & 50 & 100 \\
\hline
\end{tabular}

Sumber Data: Hasil penelitian

Tabel 1 menunjukkan bahwa masih banyak tindakan kriminal dan para korban dapat meninggal, luka-luka termasuk pelecehan seksual. Dalam memberantas premanisme di wilayah Polres Indragiri Hilir, hal itu masih terkendala. Menghirup kantor polisi untuk meningkatkan keamanan di semua area yang rawan tindakan premanisme, sehingga orang bisa merasa nyaman dalam mencari kehidupan dan tidak ada lagi rasa takut di tempat kerja (Makaampoh 2013). Dilihat dari kehidupan sehari-hari di Pelabuhan Tembilahan masih banyak preman yang menjalani kegiatan makelar. Bahkan ketika speedboat berlabuh di dermaga, para broker bergegas ke speedboat untuk menarik tas penumpang untuk pergi bersama mereka ke tempat tujuan dengan biaya yang relatif mahal.

Praktik premanisme memang dapat tumbuh dalam berbagai kehidupan masyarakat, dari masyarakat rendah hingga masyarakat terpelajar. Terutama saat ini di Indonesia mengembangkan informalitas sistem dan struktur di berbagai lembaga. Sistem dan struktur formal yang ada memunculkan sistem dan struktur informal sebagai bentuk dualisme ini (Azhar dan Satriawan ,2020). Kondisi ini telah berkembang menjadi premanisme sosiologis, karena munculnya premanisme dapat ditelusuri hingga celah yang terjadi pada struktur masyarakat. Tingkat premanisme di Kota Tembilahan disajikan pada tabel 2.

Tabel 2. Tingkat premanisme di Kota Tembilahan

\begin{tabular}{llll}
\hline No & Jawaban Responden & Jumlah Responden & Persen \\
\hline 1 & ditegakkan & 35 & 70 \\
2 & Kurang ditegakkan & 10 & 20 \\
3 & Tidak ditegakkan & 5 & 10 \\
\hline Total & & 50 & 100 \\
\hline
\end{tabular}

Sumber Data: Hasil penelitian 
Meningkatnya tindak premanisme di wilayah Polres Indragiri Hilir, sebagian karena kurangnya penegakan hukum oleh Polres Indragiri Hilir, yang berarti terjadi pertama dan kemudian bertindak, harus terus menerus dan pada titik rawan tindakan premanisme dilakukan penggerebekan, sehingga tindakan premanisme di daerah Polisi Inhil dapat ditekan dan dikurangi (Siregar dan Mukhlis, 2020). Pada saat ini banyak penjahat melakukan tindakan kriminal dalam kelompok atau organisasi, tetapi ada juga kejahatan individu. Setiap daerah memiliki pemimpin yang mengoordinasikan anak buahnya untuk melakukan tindakan premanisme. Khususnya dalam bentuk pembayaran ilegal, setiap daerah wajib menyetor hasilnya kepada pemimpin geng yang kemudian juga memberikan simpanan kepada individu tertentu. Tingkat pengetahuan publik tentang biaya ilegal yang dilakukan oleh penjahat di kota Tembilahan disajikan pada tabel 3 .

TABEL 3. Tingkat Pengetahuan Publik tentang Retribusi Ilegal

\begin{tabular}{llll}
\hline No & Jawaban Responden & Jumlah Responden & Persen \\
\hline $\mathbf{1}$ & Sangat Mengetahui & 35 & 70 \\
$\mathbf{2}$ & Kurang pengetahuan & 10 & $\mathbf{2 0}$ \\
3 & Tidak tahu & 5 & 10 \\
\hline Total & & 50 & 100 \\
\hline
\end{tabular}

Sumber Data: Hasil penelitian

Retribusi ilegal (pemerasan) yang dilakukan oleh preman di Kota Tembilahan banyak dari hal-hal ini dapat dilihat pada biaya parkir. Karena di beberapa titik di kota Tembilahan, tidak ada area parkir yang juga dipungut biaya parkir, dan bahkan biaya parkir tanpa bukti bukti yang diberikan oleh penjaga parkir (Widjiastuti, 2003). Ini tentu saja membuat nyaman bagi konsumen dan produsen, terkadang belanja hanya Rp. 5.0oo rupiah, membayar parkir Rp. Rp. 2.0oo, bahkan ketika berhenti dengan biaya parkir. Dalam hal ini Polisi Daerah Inhil harus mengambil tindakan tegas atas tindakan yang diambil oleh preman di wilayah hukum mereka. Jika dibiarkan, tentu saja akan mengganggu masyarakat, terutama pedagang yang menjual di pasar (Septiadi, Dewi, and Amrullah 2012). Berdasarkan hasil penelitian di lapangan melalui kuesioner mengenai tingkat pengetahuan masyarakat tentang tindakan yang dilakukan oleh Kantor Polisi Inhil terhadap tindakan premanisme di Kota Tembilahan sesuai dengan tabel 4. Dalam penegakan hukum terhadap premanisme dari Polres Inhil yang diharapkan oleh masyarakat Kabupaten Indragiri Hilir adalah ketegasan aparat penegak hukum, sehingga terjadi efek jera bagi pelaku kejahatan dan atau tindak premanisme. Berdasarkan hasil penelitian di lapangan melalui kuesioner tentang pengetahuan masyarakat tentang fasilitas dan infrastruktur yang disediakan oleh Polisi Inhil dalam mengurangi premanisme di Kota Tembilahan menurut tabel 5 .

Tabel 4. Tingkat Pengetahuan Publik tentang Tindakan yang diambil Kepolisian

\begin{tabular}{llll}
\hline No & Jawaban Responden & Jumlah Responden & Persen \\
\hline $\mathbf{1}$ & Sangat Mengetahui & 10 & 20 \\
\hline $\mathbf{2}$ & Kurang pengetahuan & $\mathbf{2 0}$ & 40 \\
\hline 3 & Tidak tahu & 20 & 40 \\
\hline Total & & 50 & 100 \\
\hline
\end{tabular}

Sumber Data: Hasil penelitian 
Tindakan pencegahan lebih baik daripada tindakan represif dan rehabilitasi. Upaya pencegahan tidak selalu membutuhkan organisasi atau birokrasi yang dapat mengarah pada birokratisme yang berbahaya dan penyalahgunaan wewenang atau kekuasaan. Adapun upaya pencegahan yang lebih baik daripada represif dan rehabilitasi. Untuk melayani lebih banyak orang, bahkan tidak ada kebutuhan bagi banyak pekerja seperti upaya represif dan rehabilitasi (Busyro 2019). Upaya pencegahan tidak perlu menimbulkan konsekuensi negatif seperti stigmatisasi (memberi stempel pada mereka yang dihukum atau dibina), pengasingan, menderita dalam berbagai bentuk, pelanggaran hak asasi manusia, perumusan kebencian satu sama lain yang dapat menyebabkan residivisme. Viktimisasi struktural, yaitu akumulasi korban terstruktur tentu dapat dikurangi dengan upaya pencegahan, misalnya korban sistem hukuman untuk peraturan tertentu sehingga mereka dapat menderita penderitaan mental, fisik dan sosial (Siregar, 2020).

\section{Kendala yang Dihadapi dalam Penegakan Hukum atas Perampokan Kisah Para Polisi Oleh Indragiri Hilir}

Kurangnya kesadaran publik akan pemahaman hukum dan kurangnya kepercayaan pada diri mereka sendiri. Jika kesadaran iman manusia baik, maka tidak akan ada tindakan kriminal di Kabupaten Hilir Indargiri. Hambatan yang dihadapi oleh Polres Indragiri Hilir dalam penegakan hukum terhadap tindakan premanisme, ada beberapa faktor (Makaampoh 2013):

1. Hukum, berdasarkan hasil penelitian penulis di lapangan berdasarkan penulis menyebar kuesioner mengani tingkat pengetahuan masyarakat tentang penerapan hukum oleh Polisi Inhil dalam hal pemberantasan premanisme di kota Tembilahan pada khususnya dan Inhil pada umumnya sesuai ke tabel 6.

Tabel 6. Tingkat Pengetahuan Publik Terhadap Penerapan Hukum Oleh Inhil Polres dalam Memerangi Premanisme di Inhil

\begin{tabular}{llll}
\hline No & Jawaban Responden & Jumlah Responden & Persen \\
\hline $\mathbf{1}$ & Diterapkan & 10 & 20 \\
2 & Tidak Diterapkan & 20 & 40 \\
3 & Tidak Tau & 20 & 40 \\
\hline Total & & 50 & 100 \\
\hline
\end{tabular}

Sumber Data: Hasil penelitian

Sedangkan dalam menegakkan hukum untuk memberantas tindakan premanisme di Kota Tembilahan, Kantor Polisi Inhil harus menerapkan hukum sesuai dengan KUHP, setiap orang yang melakukan harus ditangani sesuai dengan hukum yang berlaku.

2. Penegakan Hukum, dalam berfungsinya hukum, mentalitas atau kepribadian petugas penegak hukum memainkan peran penting, jika peraturannya baik, tetapi kualitas petugas tidak baik, maka penegakan hukum tidak akan berjalan dengan baik (Atika 2016). Mereka yang melakukan tindakan premanisme harus diproses sesuai dengan hukum yang berlaku dan harus sampai pada keputusan pengadilan. Dalam konteks di atas yang berkenaan dengan kepribadian dan mentalisme penegak hukum, sejauh ini telah ada kecenderungan kuat di kalangan masyarakat untuk menafsirkan hukum sebagai petugas atau penegak hukum, yang berarti bahwa hukum diidentifikasi dengan perilaku nyata petugas atau petugas atau hukum. penegak. Berdasarkan hasil penelitian penulis di lapangan berdasarkan 
Logika : Journal of Multidisciplinary Studies, p-ISSN 2085-997X. e-ISSN 2715-4505.

Vol. 11 Nomor 02 Desember 2020. 79-86.

kuesioner yang dibagikan tentang tingkat pengetahuan publik tentang ketegasan (Nugroho dkk., 2017) otoritas penegak hukum dalam memberantas premanisme di kota Tembilahan pada khususnya dan Inhil secara umum, sesuai tabel 7

Tabel 7. Tingkat Pengetahuan Publik Pihak Penegak Hukum Perusahaan dalam Memerangi Perampokan di Kota Tembilahan

\begin{tabular}{llll}
\hline No & Jawaban Responden & Jumlah Responden & Persen \\
\hline 1 & Tegas & 10 & 20 \\
\hline 2 & Kurang Tegas & 20 & 40 \\
\hline 3 & Tidak Tau & 20 & 40 \\
\hline Total & & 50 & 100 \\
\hline
\end{tabular}

Sumber Data: Hasil penelitian

Disajikan dalam bentuk teks, Tabel dan atau Gambar. Hasil dan pembahasan berisi pelaksanaan kegiatan, analisis hasil kegiatan, kendala yang dihadapi, dampak, dan upaya keberlanjutan kegiatan. Disajikan dalam bentuk teks, Tabel dan atau Gambar. Hasil dan pembahasan berisi pelaksanaan kegiatan, analisis hasil kegiatan, kendala yang dihadapi, dampak, dan upaya keberlanjutan kegiatan.

Disajikan dalam bentuk teks, Tabel dan atau Gambar. Hasil dan pembahasan berisi pelaksanaan kegiatan, analisis hasil kegiatan, kendala yang dihadapi, dampak, dan upaya keberlanjutan kegiatan. Disajikan dalam bentuk teks, Tabel dan atau Gambar. Hasil dan pembahasan berisi pelaksanaan kegiatan, analisis hasil kegiatan, kendala yang dihadapi, dampak, dan upaya keberlanjutan kegiatan. Disajikan dalam bentuk teks, Tabel dan atau Gambar. Hasil dan pembahasan berisi pelaksanaan kegiatan, analisis hasil kegiatan, kendala yang dihadapi, dampak, dan upaya keberlanjutan kegiatan.

\section{SIMPULAN}

Penegakan hukum terhadap premanisme yang dilakukan oleh Polres Indragiri Hilir masih belum sesuai harapan, karena sampai saat ini premanisme masih meresahkan masyarakat, seperti pembayaran ilegal, parkir yang tidak mengacu pada ketentuan yang berlaku dan tindak pidana lainnya. Masih banyak kendala yang harus diatasi oleh aparat penegak hukum dalam upaya penegakan hukum untuk premanisme ini, yaitu hukum yang diterapkan harus jelas, penegakan hukum harus tegas tanpa pandang bulu, partisipasi masyarakat dalam pencegahan dan penegakan hukum, sarana dan prasarana yang masih kurang dan peran pemerintah.

\section{SARAN}

Kepada pemerintah daerah bahwa penegakan hukum untuk premanisme ini harus mendapat dukungan pemerintah, yaitu hukum yang diterapkan harus disosiialisasikan duku kepada masyarakat luas, penegakan hukum harus tegas tanpa pandang bulu, partisipasi masyarakat dalam pencegahan dan penegakan hukum, sarana dan prasarana yang masih perlu dukungan dan peran pemerintah. 
Logika : Journal of Multidisciplinary Studies, p-ISSN 2085-997X. e-ISSN 2715-4505.

Vol. 11 Nomor 02 Desember 2020. 79-86.

\section{Jurnal:}

\section{DAFTAR PUSTAKA}

Achmad Miftah Farid, Hibnu Nugroho, Dwi Hapsari Retnaningrum, 2020. Pelaksanaan

Fungsi Pengawasan Terhadap Perilaku Hakim Oleh Mahkamah Agung, Soedirman

Law Review, Volume 2 No. 1 Tahun 2020. Purwokerto : FH UNSOED

Aunur Rohim Faqih, 2013. Kode Etik Dan Pedoman Perilaku Hakim, Jurnal Agama dan Hak Azazi Manusia Vol. 3, No. 1, 2013. Yogyakarta: FH UII

Diding Rahmat, 2016, "Eksistensi Lembaga Bantuan Hukum (LBH) Cirebon dalam Pendampingan Perkara Pidana di Pengadilan Negeri Cirebon", Jurnal Ilmu Hukum Vol. 3 No. 1 Januari 2016, Kuningan: FH Uniku, hlm. 1-13.

Firman Floranta Adonara, 2015. Prinsip Kebebasan Hakim Dalam Memutus Perkara Sebagai Amanat Konstitusi, Jurnal Konstitusi, Volume 12, Nomor 2, Juni 2015. Jember:

FH Universitas Jember

H. Sudirman L, Hasanuddin Hasim, Abdul Hafid, 2019. Implementasi Kode Etik Dan Pedoman Perilaku Hakim Di Ptun Makassar. Jurnal Hukum Samudra Keadilan Volume 14, Nomor 2, Juli-Desember 2019. Parepare : FHIS IAIN Parepare

Heni Hendrawati, Siti Vickie Dina, dkk, 2016. Aspek Penegakan Kode Etik Hakim DalamMewujudkan Kekuasaan Kehakiman Yang Bermartabat Dan Berintegrita, Varia Justicia Vol 12 No. 1 Maret 2016. Magelang: FH Universitas Muhammadiyah Magelang

Ismail Rumadan, 2016. Membangun Hubungan Harmonis Dalam Pelaksanaan Fungsi Pengawasan Hakim Oleh Mahkamah Agung Dan Komisi Yudisial Dalam Rangka Menegakkan Kehormatan, Keluhuran Dan Martabat Hakim, Jurnal Hukum dan Peradilan, Volume 5 Nomor 2, Juli 2016. Jakarta: FH Universitas Nasional

Umi Laili, 2017. Peran Komisi Yudisial Dalam Pengawasan Pelanggaran Kode Etik Dan Pedoman Perilaku Hakim. Jurnal LEGALITAS Volume 2 Nomor 1, Juni 2017. Samarinda : FH UNTAG

Sakirman,2017. Analisis profesi hakim dalam epistemology hukum Islam, Ijtihad, Jurnal Wacana Hukum Islam dan Kemanusiaan, Volume 17, No. 1, Juni 2017: 137-154. Lampung: IAIN Lampung

Yani Andriyani, 2019. Implementasi Kode Etik Hakim Dalam Memeriksa, Mengadili Dan Memutus Perkara, Jurnal Logika Vol. 10 Nomor o1 Juni 2019, Kuningan: FH UNIKU hlm 13-30

\section{Buku- Buku:}

Al Wisnubroto, 1997, Hakim Dan Peradilan Di Indonesia, Universitas AtmaJaya Yogyakarta, Yogyakarta, hlm. 65

Komisi Yudisial Republik Indonesia, Bahan Bacaan Klinik Etik dan Hukum, ...h. 70

Sutrisno dan Wiwin Yulianingsih, Etika Profesi Hukum, (Yogyakarta : C.v Andy Offset,2016), h. 236

Internet : 
Logika : Journal of Multidisciplinary Studies, p-ISSN 2085-997X. e-ISSN 2715-4505.

Vol. 11 Nomor 02 Desember 2020. 79-86.

Devina Halim, KY Ungkap Dua Alasan Maraknya Pelanggaran Hakim, diakses di https://nasional.kompas.com/read/2018/og/o6/21011321/ky-ungkap-duaalasan- $\quad$ maraknya-pelanggaran-hakim, pada pukul 14.20 WIB 14 April 2020.

\section{Perundang-Undangan :}

Undang-Undang Dasar 1945

Undang-Undang Nomor 48 tahun 2009 tentang Kekuasaan Kehakiman

Undang-Undang Nomor 18 Tahun 2011 Tentang Komisi Yudisial

Peraturan Bersama Ketua Mahkamah Agung Republik Indonesia Dan Ketua Komisi Yudisial Republik Indonesia Nomor : 02/PB/MA/IX/2012- 02/PB/P.KY/09/2012 Tentang Panduan Penegakan Kode Etik Dan Pedoman Perilaku Hakim

Surat Keputusan Bersama Ketua Mahkamah Agung Republik Indonesia dan Ketua Komisi Yudisial Republik Indonesia Nomor: 047/KMA/SKB/IV/2009 02/SKB/P.KY/IV/2009 tanggal 8 April 2009 Tentang Kode Etik dan Pedoman Perilaku Hakim 